\title{
Кондратенко Лариса Олександрівна
} доктор психологічних наук, провідний науковий співробітник,

Інститут психології імені Г. С. Костюка НАПН України

\section{МОТИВАЦІЯ ДО УЧІННЯ \\ В СИТУАЦІЇ НЕДОВИЗНАЧЕНОСТІ ЖИТТЕВИХ ЗАДАЧ}

\begin{abstract}
Анотація. У статті представлено результати пілотажного вивчення мотивації до учіння одинадиятикласників, яка відбувається в ситуації недовизначеності життєвих задач, за допомогою тестоподібної методики «Лист до друга в соимережі». Мотивація до учіння - изе складне багатоаспектне явище, і його дослідження за допомогою простих опитувальників не завжди дає повну картину. До того ж частина тестованих намагається показати себе з кращої сторони, щуо суттєво впливає на достовірність отримуваних результатів. Тому доцільно використовувати проективні й напівпроективні методики, до яких належить $i$ «Лист до друга в сочмережі». За його допомогою вдалося виявити, щуо значна частина одинадиятикласників орієнтована лише на найближчу задачу - здачу ЗНО, а вже за його результатами збираються обирати вуз. Такий підхід негативно впливає на ставлення до учіння: мета майстерності замінясться метою перформансу.
\end{abstract}

Ключові слова: мотивація, учіння, методики діагностики, мета, тип мотиваџіï, плани на майбутнє, стариі підлітки.

Мотивація школярів до учіння завжди була і залишається тією проблемою, яка постійно хвилює дитячих педагогів та психологів. Останнім часом у цій царині з'явились дослідження, які дають змогу побачити нові аспекти цієї проблеми. Зокрема, у працях таких психологів, як C. Ames, S. C. Broussard, M. E. B Garrison, A. E. Gottfried, J. S. Fleming, A. W. Gottfried, S. Hidi, J. M. Harackiewicz, E. R. Lai, L. Legault, S. M. Yilmaz, M. G. Zeleny, R. Zhao, R. H Bruning, M. S. Dempsey та D. F. Kauffman особлива увага звертається на зв'язок між усвідомлюваними життєвими задачами (цілями), типами мотивації та успішністю у шкільному навчанні та подальшому житті.

Важливе місце в сучасних західних дослідженнях займає проблема внутрішньої та зовнішньої мотивації учіння. В основі обох типів мотивації лежать цінності, важливі для певної особистості. Водночас цінності розглядаються як стимули чи причини для участі в діяльності [5]. Особистісна цінність певної діяльності може мати чотири компоненти: цінність досягнення, яка відноситься до особистісної цінності добре виконувати роботу (поставлене завдання); внутрішня цінність (цінність, що $є$ складовою особистості індивіда), яка відноситься до суб'єктивного інтересу або задоволення від виконання завдання; утилітарна цінність, за якої виконання завдання сприймається як таке, що має полегшити здійснення 
поточних або майбутніх цілей; і ціна (cost), а не цінність (value), що стосується негативних аспектів, які може викликати участь у виконанні завдання, - зокрема, це тривога і відчуття поразки $[5 ; 10 ; 8]$.

Як стверджує E. R. Lai, поняття внутрішньої (intrinsic) мотивації тісно пов'язане 3 внутрішньою цінністю. Внутрішня мотивація відноситься до мотивації, яка анімована (is animated) особистою насолодою, інтересом або задоволенням, і зазвичай протиставляється зовнішній мотивації, яка управляється додатковими підсиленнями Здебільшого вплив за допомогою зовнішньої мотивації здійснюється з використанням стимулу винагороди, яка може бути або матеріальною (гроші, оцінки, привілеї тощо) або нематеріальною (похвала, покращання іміджу, підвищення власного статусу в суспільстві). Важливими факторами впливу у зовнішній мотивації виступає внутрішнє бажання винагороди або запобігання покарання.

В «Енциклопедії особистості та індивідуальних відмінностей» (Encyclopedia of Personality and Individual Differences) L. Legault внутрішню мотивацію визначає як таку, що спонукає діяльність, яка сама по собі може приносити задоволення або радість (satisfying or enjoyable). Така діяльність важлива сама по собі, вона не $\epsilon$ прив'язаною до певного результату. Зовсім інша ситуація із зовнішньою мотивацією, яка принципово залежить від досягнення в результаті діяльності певного результату. Зовнішня мотивація є багатовимірною і може породжуватись як зовнішніми, так і внутрішніми чинниками. Головною відмінністю від внутрішньої мотивації $є$ те, що сама по собі стимульована нею діяльність не приносить задоволення, вона може бути навіть дуже обтяжливою для особистості, однак результат цієї дії є бажаним.

До змішаної форми мотивації E. R. Lai відносить мотивацію поведінки, зумовлену внутрішнім тиском, таким, як зобов'язання або відчуття провини.

Проведені дослідження [2; 3; 6] свідчать про те, що хороша внутрішня мотивація співвідноситься як з кращими успіхами у навчанні, так і життєвою успішністю в цілому.

Іншим важливим аспектом мотивації виступає мета мотивованої діяльності, чого, власне, хоче досягти певна особистість. Broussard та Garrison виокремлюють цілі майстерності та цілі перформансу. В чому різниця? Цілі майстерності зосереджені на навчанні заради навчання, самоцінності навчання, задоволенні власних пізнавальних потреб, тоді як цілі перформансу показати оточенню свої досягнення. Цілі майстерності пов'язані з високою здатністю до аналізу інформації та планування, і вірою, що зусилля покращують можливості людини. 3 іншого боку, цілі перформансу супроводжуються думками про досягнення, оцінки, зовнішні нагороди. На перший погляд здається, що цілі майстерності, як і цілі перформансу, можуть бути однаково важливими для формування високої мотивації до учіння. Однак, як виявили 
дослідження Connell, Wellborn, Eccles, Wigfield, Weiner (подаються в описі E. R. Lai), індивід буде настільки мотивований, наскільки відчуватиме, що він сам контролює свої власні успіхи та невдачі. Величезну роль у цьому відіграє локус контролю. В одному із визначень теорії локусу контролю автономія виступає однією із трьох базових психологічних потреб нарівні 3 компетенцією та зв'язністю (relatedness) понять у системі знань. Локус контролю тісно прилягає до концепту (поняття) атрибуцій. Атрибуції стосуються переконань індивіда щодо причин успішної або невдалої роботи. Відповідно до теорії атрибуцій типи атрибуцій, яких притримується людина визначають рівень іiі мотивації залежно від того чи сприймається певна подія як щось, що може бути зміненим і знаходиться під контролем людини. Наприклад, вроджені здатності є відносно (relatively) стабільними характеристиками, на які важко впливати. 3 іншого боку - зусилля знаходиться в межах людського контролю і ними можна цілком маніпулювати. Однак параметри певного завдання, а також удача знаходяться поза межами людського контролю і мають тенденцію до варіабельності.

Отже, погана продуктивність в ході вирішення задачі (виконання завдання) призведе до зменшення зусиль та падіння мотивації швидше у тих, хто вважає, що йому не вистачає здібностей, ніж у тих, хто пов'язує успіх із витраченими зусиллями, оскільки нездатність для першої групи означає неможливість, яку важко змінити, тоді як невдача для другої групи означає, що для успіху просто треба витратити більше зусиль. Так само цілі перформансу безпосередньо залежать від зовнішньої оцінки успішності діяльності, місця індивіда в соціумі, а цілі майстерності більше спираються на внутрішній потенціал людини. Тому люди, мотивовані на цілі перформансу, можуть легше ламатися і втрачати продуктивність власної мотивації, аніж люди, мотивовані на цілі майстерності, які навіть у випадку довготривалих невдач зберігають віру в себе та внутрішню мотивацію діяльності.

Розглянемо взаємини між цими діючими факторами (задачі, типи мотивації) в ситуації вибору старшокласниками життєвих цілей.

\begin{tabular}{|c|c|c|c|c|}
\hline Загальна мета & \multicolumn{3}{|c|}{ Планування найближчого майбутнього } \\
\hline Задача & \multicolumn{3}{|c|}{ Розуміння значення учіння для досягнення мети } \\
\hline Тип мотивації & $\begin{array}{c}\text { Внутрішня } \\
\text { мотивація }\end{array}$ & Більш ефективна & Зовнішня & Менш ефективна \\
& Майстерності & Більш ефективна & Перформансу & Менш ефективна \\
\hline $\begin{array}{c}\text { Ціль мотивованої } \\
\text { діяльності }\end{array}$ & Інтернальний & Більш & Екстернальний & Менш \\
Локус контролю & ефективний & & ефекивнй \\
\hline
\end{tabular}


Як ми бачимо з таблиці, різні фактори можуть підсилювати або послаблювати мотивацію індивіда на виконання певної діяльності.

Для вивчення особливості мотивації старшокласників було розроблено тестоподібну методику «Лист до друга в соцмережі». В iï основі лежить підхід, запропонований Ю. З. Гільбухом: «Методика являє собою комбінацію трьох психодіагностичних методів: аналізу продуктів діяльності, опитувальника і проективної техніки. На уроці мови чи літератури підліткам, старшокласникам пропонується написати лист до друга - реального чи вигаданого - від власного імені або від імені уявного автора (вибір визначається задумом педагога). Мотивується такого роду завдання необхідністю розвитку у школярів елементарних літературно-творчих здібностей. Незадоволена потреба в сповідальності, яка відчувається більшістю підлітків і старшокласників, знаходить в цьому творі свій адекватний предмет. I хоча вони прекрасно усвідомлюють, що лист буде прочитаний сторонніми (учителем, психологом-експериментатором), проте з безсумнівною відвертістю і щирістю діляться своїми поглядами і переживаннями. Конкретна тематика, яка визначається психодіагностичним задумом педагога, задається шляхом пред'явлення готової експозиції - «питання друга», на які належить дати відповідь, наприклад: «Ти просиш розповісти про моє життя, зокрема про взаємини з батьками. Що ж, спробую це зробити...».

Психодіагностична цінність описаної методики полягає не тільки в можливості визначити знання в області етики, особисті думки і внутрішні соціальні установки школяра 3 того чи іншого питання - учитель отримує, крім того, цілісну картину його реальної поведінки в цікавій для нього сфері. Запропонувавши учням написати лист від імені вигаданого автора (і тим самим надавши методиці риси проективної техніки), ви створюєте додаткову гарантію проти спотворень у висловлюваннях школярів, викликаних бажанням показати себе в кращому світлі» [1, с. 84-85].

Створеній Ю. З. Гільбухом методиці вже більше тридцяти років і їі досить широко використовують як практичні психологи, так і науковці лабораторії психодіагностики (зараз психодіагностики та науково-психологічної інформації) Інституту психології імені Г. С. Костюка НАПН України. Однак досвід показав, що з часом вона дещо застаріла i потребує модифікації, оскільки сучасні діти не пишуть листів, а спілкуються переважно в соціальних мережах, де можлива анонімність. Звичка до анонімності викликає підозру стосовно будь-якого авторизованого тесту, до того ж старші підлітки взагалі є дещо складною для тестування популяцією внаслідок їхньої внутрішньої опозиції до світу дорослих. Тому пропонований варіант для вивчення мотивації до учіння передбачає використання не імен, а нікнеймів. Нікнейми потрібні для порівняння результатів, отриманих внаслідок аналізу результатів тестування за різними методиками, включно із традиційними опитувальниками. 
Іншою новацією методики названою «Переписка із другом»є долучення другої частини - відповіді віртуального друга. Ця відповідь дає можливість подивитися на різницю розуміння проблеми на рівні его та супер-его, глибше виявити роль батьківського впливу на прийняття рішень.

Сама методика складається з інструкції (ії виголошує той, хто проводить тестування) і двох бланків - для листа другові та його відповіді.

Інструкція. Добрий день. Сьогодні ми попрактикуємось у написанні листів. Зараз багато з вас мають друзів в соціальних мережах і переписуються з ними. Ті ж, у кого таких друзів немає, все одно знають про можливість їх існування. Однією 3 особливостей такого листування виступає його повна анонімність, що дає змогу вам розмовляти 3 таким віртуальним другом з повною відвертістю, адже ви навіть справжнього імені його не знаєте, а він не знає вашого. Ви (і ваш комп'ютерний друг) використовуєте так звані нікнейми, які $€$ вашим обличчям в мережі, яке, за бажання, може відображати (а може і не відображати) вашу сутність, прагнення, характер, інтереси. Зараз ми спробуємо написати два листи: ваш до друга і його до вас. Початок листів наведений у вас на листочках Підписуйтесь тільки нікнеймами. Якщо таких немає - придумайте. Можете використовувати смайлики.

1 бланк. Лист до друга.

\section{Привіт, (нікнейм друга)!}

У мене проблеми, і я хотів (хотіла) б з тобою порадитися. Мої батьки раптом занепокоїлися моїм майбутнім і чіпляються до мене з питанням - ким я збираюся бути і що для цього збираюся робити. Я постарався (постаралася) відповісти, що ...

А ти як думаєш - це правильно? 3 привітом (ваш нікнейм).

2 бланк. Відповідь друга.

Привіт, (нікнейм адресата, тобто тебе як автора першого листа)!

Я прочитав (прочитала) твій лист і, в принципі, з тобою згоден (згодна). Тільки може я б ще додав (додала), що ...

Бажаю тобі всього хорошого і щоб батьки тебе не «діставали». (Нікнейм друга, якому був адресований твій лист).

За цією методикою обстеження старшокласників тільки почалося, але проведене пілотажне тестування показало, що вона дає змогу побачити дуже цікаві тенденції в мотивації учнів 11 класу. У тестуванні взяли участь 27 учнів міської школи міста обласного значення та 7 учнів сільської школи (у селі зберегли загальноосвітню школу попри дуже малу наповненість класів). Тестування проходило в кінці 2018 року.

Проаналізуємо їх у відповідності до запропонованої схеми. 


\section{1. Планування найближчого майбутнього.}

У ході аналізу листів виявилась досить неочікувана тенденція. Із семи майбутніх випускників сільської школи четверо уже спланували своє найближче майбутнє. Вони будуть намагатися вступити до чітко визначеного вузу і зараз роблять все можливе, щоб краще здати екзамени:

"...Я готуюся до вступу у медичний коледж. Для здійснення своєї мрії я иікавлюсь усім, щุo пов'язане з медищиною $і$ додатково знайомлюсь із біологією, щэоб орієнтуватись $у$ медичних термінах, знати будову та роботу людських організмів...";

" ...Буду старанно вчитися. I моя майбутня професія буде пов'язана з навчанням дітей у школі...";

У тих, хто не визначився, наявний відкритий конфлікт із батьками:

"...Я ще не обрала, ким хочу бути в майбутньому. Вони почали підвищувати голос на мене. Я на них дуже образилася. Ми з ними тепер не спілкуємося через це. Це мене образило, щзо вони почали на мене кричати...";

У міській школі старшокласників, які точно визначились із майбутнім, у процентному відношенні значно менше (8 учнів):

"...Мне нравятся точные науки, и я бы хотела связать свое будущее с этими предметами. Я посоветовалась с родителями и решила поступать на факультет программистики, так как мне это интересно. Сейчас мои родители помогают мне с учебой, потому что хотят, чтобы в будущем я достигла всего того, что я хочу сейчас. Я стараюсь изо всех сил сейчас учить все, что мне рассказывают учителя, я понимаю, что от того как я буду учиться сейчас зависит мое будущее...";

"...Мне нравится изучать филологию и литературу. Я люблю писать сочинения и читать разные книги, я выбрала профессию, связанную с этим направлением. Сейчас я упорно стараюсь осуществить мою мечту - поступить в высшее учебное заведение и достичь поставленной цели - успешно сдать ЗНО. Я очень надеюсь, что приложив старания и труд, у меня все получится...";

"..Хочу в будущем стать переводчиком. Я сказала, что мне пригодится знание иностранных языков, поэтому я старательно изучаю английский ".

Останні 19 одинадцятикласників за півроку до закінчення школи поділилися майже порівну на тих, хто просто орієнтований на те, щоб здати ЗНО і за його результатами збирається підбирати "підхожий" вуз, і тих, хто взагалі не визначився, що буде робити окрім того, що здаватиме 3НО, вступатиме до вузу, а далі "робитиме гроші і кар'єру":

"...У майбутньому я хочу працювати у сфері бізнесу. І щоб у мене все вийшло, я повинна старанно вчитися і готуватися до ЗНО..."; 
"...Підготовка до ЗНО зараз іде дуже активно, навчання у школі теж не дає відпочивати. Це важко, але я роблю все, щоб піти навчатися далі, робити кар'єру і т. д..."

"Я пытаюсь старательно учиться, я детально изучаю те предметы, по которым собираюсь сдавать ЗНО, а там будет видно...";

"Я сама еще не знаю, кем я хочу быть. И мне нужна помощь близких. Я посоветовалась с братом о своей будущей профессии, чтобы он помог мне с выбором, так как родители не дали нужных мне советов...";

"...Я ще не знаю, ким я хочу бути. Моїм батькам не сподобалось це і вони сказали, що якщо я не визначусь із цим питанням, то вони візьмуть усе в свої руки ...";

"...Ничего не ответила. Они за меня все решили и точка. Вот такие у меня родители. Не жизнь, а праздник...".

Лише один хлопець, серед тих, хто проходив тестування, має плани на випадок невдачі із вступом до вузу:

"...Если я не наберу достаточно баллов для бюджета, то пойду работать к папе на CTO...".

\section{2. Розуміння значення учіння для досягнення визначеної в процесі планування} мети.

Слід визнати, що справжнє розуміння значення учіння наявне лише у тих, хто точно визначився з планами на найближче майбутнє і для яких ЗНО не мета, а лише засіб.

\section{3. Тип мотивації (внутрішня, зовнішня).}

У переважної більшості одинадцятикласників переважає зовнішня мотивація. Тільки двоє із протестованих підлітків виявили внутрішню мотивацію - я люблю літературу, пишу оповідання, тому буду займатись філологією; люблю конструювати, будувати - буду старатись стати архітектором.

\section{4. Ціль учіння (майстерності, перформансу).}

3 огляду на важливість для випускників здачі ЗНО, цілі майстерності відходять на другий план, а переважають цілі перформансу.

\section{5. Локус контролю (інтернальний, екстернальний).}

Застосована методика не дала можливості визначити локус контролю у протестованих одинадцятикласників.

Проведене дослідження, хоч і мало орієнтовний характер, дало змогу зробити попередні висновки щодо особливостей мотивації старших підлітків у ситуації недовизначеності життєвих задач, коли планування майбутнього знаходиться на стадії попереднього осмислення. Виявлено, що межі мотивації учіння звужені до задачі здачі ЗНО та вступу до вузу. Справжнє розуміння значення учіння наявне лише у тих, хто точно визначився з планами 
на найближче майбутнє і для яких ЗНО не мета, а лише засіб, зовнішня мотивація у більшості випадків сильніша за внутрішню, а цілі перформансу переважають цілі майстерності.

\section{СПИСОК ВИКОРИСТАНИХ ДЖЕРЕЛ}

1. Гильбух Ю. 3. Психодиагностическая функция учителя: пути реализации/ Вопросы психологии. 1989. № 3. С. 80-88.

2. Ames, C. (1992). Classrooms: Goals, structure, and student motivation. Journal of Educational Psychology, 84(3), 261-271.

3. Broussard, S. C., \& Garrison, M. E. B. (2004). The relationship between classroom motivation and academic achievement in elementary school-aged children. Family and Consumer Sciences Research Journal, 33(2), 106-120.

4. Connell JP, Wellborn JG. 1991. Competence, autonomy, and relatedness: a motivational analysis of self-system processes. In Minnesota Symposia on Child Psychology, ed. M Gunnar, LA Sroufe, 23:43-77.

5. Eccles, J. S., Wigfield, A. (2002). Motivational beliefs, values, and goals. Annual Review of Psychology, 53, 109-132.

6. Gottfried, A. E., Fleming, J. S., \& Gottfried, A. W. (2001). Continuity of academic intrinsic motivation from childhood through late adolescence: A longitudinal study. Journal of Educational Psychology, 93(1), 3-13.

7. Hidi, S., \& Harackiewicz, J. M. (2000). Motivating the academically unmotivated: A critical issue for the 21st century. Review of Educational Research, 70(2), 151-179.

8. Lai Emily R. (2011) Motivation: A Literature Review: Research Report. URL: https://images.pearsonassessments.com/images/tmrs/Motivation_Review_final.pdf

9. Legault L. (2016) Intrinsic and Extrinsic Motivation. In: Zeigler-Hill V., Shackelford T. (eds) Encyclopedia of Personality and Individual Differences. Springer, Cham - URL: https://link.springer.com/referenceworkentry/10.1007\%2F978-3-319-28099-8_1139-1

10. Stipek, D. J. (1996). Motivation and instruction. In D. C. Berliner \& R. C. Calfee (Eds.), Handbook of educational psychology (pp. 85-113). New York: Macmillan.

11. Weiner, B. (1992). Human motivation: Metaphors, theories, and research. Thousand Oaks, CA, US: Sage Publications, Inc.

12. Yilmaz Soylu M, Zeleny MG, Zhao R, Bruning RH, Dempsey MS and Kauffman DF (2017) Secondary Students' Writing Achievement Goals: Assessing the Mediating Effects of Mastery and Performance Goals on Writing Self-Efficacy, Affect, and Writing Achievement. Front. Psychol. 8:1406. doi: 10.3389/fpsyg.2017.01406 


\section{REFERENCES}

1. Hylbukh Yu. Z., 1989. Psykhodyahnostycheskaia funktsyia uchytelia: puty realyzatsyy [Psychodiagnostic function of the teacher: ways to implement]. Voprosy psykholohyy. № 3. S. 8088.

2. Ames, C., 1992. Classrooms: Goals, structure, and student motivation. Journal of Educational Psychology, 84(3), 261-271

3. Broussard, S. C., \& Garrison, M. E. B., 2004. The relationship between classroom motivation and academic achievement in elementary school-aged children. Family and Consumer Sciences Research Journal, 33(2), 106-120.

4. Connell JP, Wellborn JG., 1991. Competence, autonomy, and relatedness: a motivational analysis of self-system processes. In Minnesota Symposia on Child Psychology, ed. M Gunnar, LA Sroufe, 23:43-77.

5. Eccles, J. S., Wigfield, A., 2002. Motivational beliefs, values, and goals. Annual Review of Psychology, 53, 109-132

6. Gottfried, A. E., Fleming, J. S., \& Gottfried, A. W., 2001) Continuity of academic intrinsic motivation from childhood through late adolescence: A longitudinal study. Journal of Educational Psychology, 93(1), 3-13.

7. Hidi, S., \& Harackiewicz, J. M.. 2000. Motivating the academically unmotivated: A critical issue for the 21st century. Review of Educational Research, 70(2), 151-179.

8. Lai Emily R.. 2011. Motivation: A Literature Review :Research Report - URL: https://images.pearsonassessments.com/images/tmrs/Motivation_Review_final.pdf

9. Legault L., 2016. Intrinsic and Extrinsic Motivation. In: Zeigler-Hill V., Shackelford T. (eds) Encyclopedia of Personality and Individual Differences. Springer, Cham - URL: https://link.springer.com/referenceworkentry/10.1007\%2F978-3-319-28099-8_1139-1

10. Stipek, D. J., 1996. Motivation and instruction. In D. C. Berliner \& R. C. Calfee (Eds.), Handbook of educational psychology (pp. 85-113). New York: Macmillan.

11. Weiner, B., 1992. Human motivation: Metaphors, theories, and research. Thousand Oaks, CA, US: Sage Publications, Inc.

12. Yilmaz Soylu M, Zeleny MG, Zhao R, Bruning RH, Dempsey MS and Kauffman DF, 2017. Secondary Students' Writing Achievement Goals: Assessing the Mediating Effects of Mastery and Performance Goals on Writing Self-Efficacy, Affect, and Writing Achievement. Front. Psychol. 8:1406. doi: 10.3389/fpsyg.2017.01406 
Kondratenko L. O. MOTIVATION TO STUDY IN A SITUATION OF UNIMPORTANCE OF LIFE TASKS

Summary. The motivation of schoolchildren to study belongs to those problems that is constantly worried by children's teachers and psychologists. Particularly important, it acquires during the active reflection of older teens about their future.

The motivation for studying is a complex multidimensional phenomenon and its research with the help of simple questionnaires does not always give a complete picture. In addition, some of the adolescents during the testing trying to show themselves on the best side, which significantly affects the reliability of the results. Therefore, it is advisable to use projective to which belongs "Letter to friend in social network". It is based on the approach proposed by Yu.Z.Gilbukh in the "Letter to Friend" method. However, experience has shown that in the course of time it is needs modification, becouse modern children do not write letters, but communicate mainly in social networks where there is absolute anomy

Completed in accordance with the modern features and needs of specific testing, the test includes not only a letter to a friend, but also the second part - the letter-reply of a virtual friend.

This answer allows us to look at the difference in understanding the problem at the level of ego and his super-ego, to deeper identify the role of parental influence on decision-making.

The research, although of its limited indicative nature, allowed us to draw preliminary conclusions about the peculiarities of the motivation of older teenagers in the situation of inadequate life tasks, when the planning of the future is at the stage of prior comprehension. It was revealed that the boundaries of study motivation are narrowed to the task of passing external independent assessment and entrance to the university. The true understanding of the meaning of the textbook is available from those who are precisely defined with plans for the near future and for which external independent assessment is not a goal, but only a means, external motivation, in most cases, is stronger than internal, and the goals of the performance are dominated by the goals of mastery. 